\title{
Non-segregated municipal solid waste in an open dumping ground: a potential contaminant in relation to environmental health
}

\author{
T. Karak $\cdot$ P. Bhattacharyya $\cdot$ T. Das $\cdot$ \\ R. K. Paul • R. Bezbaruah
}

Received: 21 July 2011/Revised: 3 December 2011/ Accepted: 23 March 2012/Published online: 7 February 2013

(C) Islamic Azad University (IAU) 2013

\begin{abstract}
The present article discusses an overview on the contamination of non-segregated open municipal solid waste (MSW) in and around a dumping site at Garchuk in Guwahati city, Assam, India. Analysis showed depth-wise variations in the concentrations of selected heavy metals in MSW and their subsequent accumulations with increasing depths. Zinc was the most abundant heavy metal in MSW. Six-step selective sequential extractions revealed that most of the heavy metals in MSW were in the residual phase except zinc. Analysis of the leachate from MSW showed high concentrations of fluoride, chloride, ammonium-nitrogen and the ratio of biological oxygen demand/chemical oxygen demand. Concentrations of all the heavy metals in the leachates were higher than the Indian national effluent standards. High amounts of biological oxygen demand, heavy metals, total and fecal coliforms in water samples from the adjoining water body (Deepor Beel, a Ramsar site) of the MSW dumping site indicated its unsuitability for domestic use. Principle component analysis showed that influence of MSW leachate was the major source of water
\end{abstract}

\section{T. Karak}

Pollution Control Board, Bamunimaidam,

Guwahati 781 021, Assam, India

\section{T. Karak ( $\square)$}

Department of Soil, Tocklai Experimental Station, Tea Research

Association, Jorhat 785 008, Assam, India

e-mail: tanmay.karak@gmail.com

\section{P. Bhattacharyya}

Department of Environmental Sciences, University of California,

Riverside, CA 92521, USA

e-mail: pradip.bhattacharyya@gmail.com

P. Bhattacharyya

Indian Statistical Institute, North East Centre, Tezpur 784 028,

Assam, India contamination in Deepor Beel. Though accumulation of heavy metals in different vegetables growing in MSW dumping site did not exceed the recommended maximum intake, it was a significant additional source of heavy metals in cooked human diet.

Keywords Heavy metals - Selective sequential extraction - Leachate $\cdot$ Water contamination $\cdot$ Vegetables

\section{Introduction}

Exponential growth of population, urbanization, development of socio-economy coupled with the improvement of living standard, has resulted in a phenomenal increase in the amount of municipal solid waste (MSW) generation throughout the world and so in India (Karak et al. 2012). Kumar and Gaikwad (2004) forecasted that in India the quantity of MSW will increase from 46 million tons per

\author{
T. Das \\ Department of Ecology and Environmental Science, \\ Assam University, Silchar 788 011, Assam, India \\ R. K. Paul \\ Division of Biometrics and Statistical Modelling, \\ Indian Agricultural Statistics Research Institute, \\ New Delhi 110 012, India \\ R. Bezbaruah \\ Life Science Division, Institute of Advance Study \\ in Science and Technology, Paschim Boragaon, \\ Garchuk, Guwahati 781 035, Assam, India
}


year in 2001 to 65 million tons per year in 2010. According to the estimates, Indian metropolitan cities alone generate about 14 million tons of MSW annually (Shekdar 2009). The state Assam in India, wherein the present study was conducted, generates 196 tons of MSW everyday (Sharholy et al. 2008). The waste generation rate in Guwahati city (capital of Assam) is approximately $0.223 \mathrm{~kg}$ per capita per day (Karak et al. 2012). Among many viable solutions to counter the increasing global problem of MSW, landfilling/ composting and incineration have widely been accepted for its ultimate sustainable management (Renou et al. 2008). Several studies have reported high concentrations of heavy metals (HMs) in an open MSW dumpsite in developing countries (Mitra et al. 2003; He et al. 2006; Bhattacharyya et al. 2008a; Prechthai et al. 2008; Biswas et al. 2010). However, there is scanty information regarding the depthwise variation in metal contaminants versus their corresponding concentrations of HMs in MSW landfill sites in India.

In India, highly decomposed MSW from the bottom layer of dumping site is collected and is used as MSW compost (MSWC) which has been gaining popularity as an organic and a plant nutritional soil supplement (Bhattacharyya et al. 2003, 2005). However, there is an increasing concern in application of MSWC prepared from non-segregated MSW in agricultural crops owing to its high concentration of HMs. To achieve proper management of MSW disposal, Government of India has also installed sophisticated incinerator plant in a number of metropolitan cities such as Kolkata, Mumbai, Chennai, Delhi and Bengaluru. However, all other cities of the country are beyond the scope of MSW disposal management (Karak et al. 2012).

Therefore, against this backdrop, an attempt was made to study the properties of MSW at Garchuk, an open MSW landfilling area of approximately 10 hectares in Guwahati (Assam), India in December, 2007. It is situated on the bank of a freshwater lake locally known as Deepor Beel, which is also a Ramsar Site. The investigation had the following objectives: (1) depth-wise characterization and assessment of total HMs (arsenic: As; zinc: Zn; cadmium: $\mathrm{Cd}$; chromium: $\mathrm{Cr}$; nickel: $\mathrm{Ni}$; lead: $\mathrm{Pb}$; mercury: $\mathrm{Hg}$ and copper: $\mathrm{Cu}$ ) in MSW dumping site, (2) selective sequential extraction of HMs in MSW, (3) analysis of important physical, chemical and bacteriological [total coliforms (TCF) and fecal coliforms (FCF)] characteristics of MSW leachate and surface water from the nearby Ramsar site, (4) assessment of HMs in selected vegetables growing in MSW dumping site, (5) assessment of the risk of ingestion of HMs through human consumption of those vegetables and (6) characterization of solid and liquid (leachate and water) materials by means of principle component analysis (PCA).

\section{Materials and methods}

Study area

The present investigation was carried out in and around an open non-segregated and non-engineered MSW dumping site at Garchuk $\left(26^{\circ} 7^{\prime} 48^{\prime \prime} \mathrm{N}, 91^{\circ} 39^{\prime} 36^{\prime \prime} \mathrm{E}\right)$, Guwahati, in the state of Assam, India, during winter season in 2007. It spreads over an area of approximately $1 \times 10^{5} \mathrm{~m}^{2}$ and wastefill height varies from 3 to $3.5 \mathrm{~m}$. The site is located in the southwest corner of Guwahati city $\left(26^{\circ} 10^{\prime} \mathrm{N}\right.$, $91^{\circ} 45^{\prime} \mathrm{E}$ ) which is approximately $12 \mathrm{~km}$ away from the city center (Fig. 1). The non-segregated MSW is generally collected by the city municipal corporation authorities from MSW bins placed at different locations of the city and are dumped at Garchuk site which are later on spreaded over a surface by mechanical spreading followed by its amalgamation.

MSW sampling, preparation and analysis

Depth-wise representative solid waste samples were randomly collected from the heap of dumping site and its surrounding areas. A total of 39 samples from 13 sampling locations (representing the study area) were collected from depths of 0-1 m (MSW1), 1-2 m (MSW2) and 2-3 m (MSW3) using backhoe excavator machine. One sampling point was selected at the center heap of the dumpsite and other twelve sampling points were chosen at $50 \mathrm{~m}$ intervals in the east, west, south and north directions from the center heap. The compositions of MSW samples were categorized as bio-medical waste (BMW), ceramics, garden trimmings

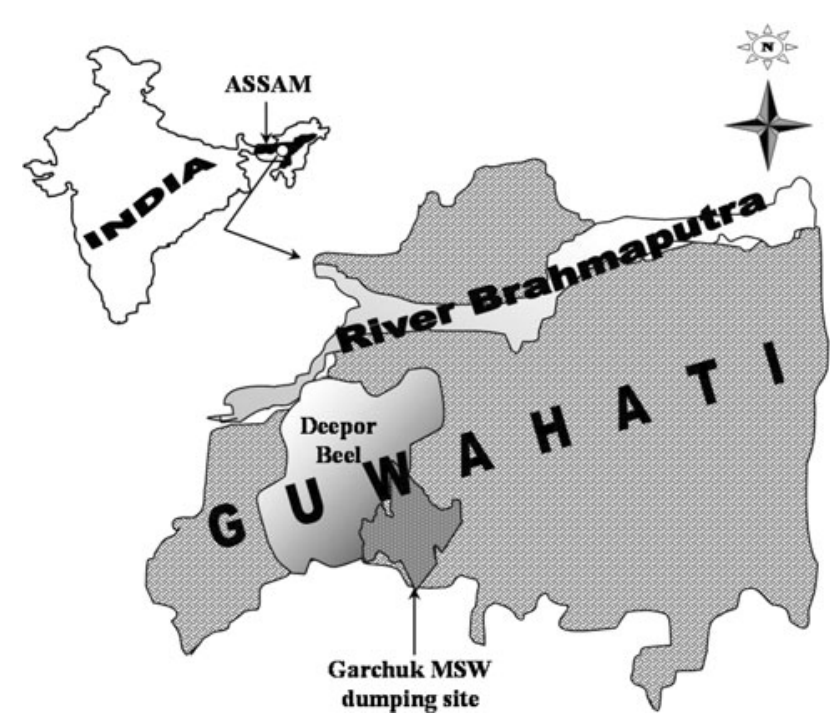

Fig. 1 Map showing the location of MSW dumping site and Deepor Beel at Garchuk, Assam, India (not to scale) 
(GTR), glass, kitchen waste (KW), metal, paper, plastic, soil, textiles, wood and others.

The samples were later segregated, homogenized and air-dried. Finally three composite samples were prepared for carrying out the study. The air-dried samples were grounded and sieved through a $1.0 \mathrm{~mm}$ mesh and was subjected to analysis for various physico-chemical parameters. In brief, moisture was determined gravimetrically in duplicate, by drying $50 \mathrm{~g}$ of sample at $105{ }^{\circ} \mathrm{C}$ to drive off water in the sample until the weight remained constant (Jackson 1995). Volatile solids were then measured by loss of weight on ignition of oven-dried samples at $550{ }^{\circ} \mathrm{C}$ for $16 \mathrm{~h}$. The measurement of the sample $\mathrm{pH}$ was carried out on sample slurries having sample/water ratios as 1:2.5 using a pH meter (Systronics India Ltd., model 239). Electrical conductivity (EC) was determined on sample slurries having sample/water ratios as 1:5.0 with a conductivity meter (Systronics India Ltd. model 507). Clay content was determined by a sieving and pipette method after the removal of organic matter with $30 \% \mathrm{H}_{2} \mathrm{O}_{2}$. Cation exchange capacity (CEC) was determined with $\mathrm{BaCl}_{2}$-triethanolamine following the method of Lax et al. (1986). Organic carbon was determined according to Nelson and Sommers (1982). Humus carbon in solid samples was measured following the procedure described by Sanchez-Monedero et al. (1996). For determination of total N (TN), samples were decomposed using concentrated $\mathrm{H}_{2} \mathrm{SO}_{4}$ and catalyst mixture in Kjeldahl flask and subsequently $\mathrm{N}$ content was determined following steam distillation and titration method (Bremner and Mulvaney 1982). Sample was oxidized at $1,100{ }^{\circ} \mathrm{C}$ in the presence of tungstic anhydride $\left(\mathrm{WO}_{3}\right)$ for the measurement of total $\mathrm{S}$. For total $\mathrm{HMs}(\mathrm{Cu}, \mathrm{Cr}, \mathrm{Cd}, \mathrm{Ni}, \mathrm{Pb}$ and $\mathrm{Zn})$ and $\mathrm{As}$ analysis, $1.00 \mathrm{~g}$ of ground MSW sample was placed in an Erlenmeyer flask, and $3 \mathrm{~mL}$ of concentrated $\mathrm{HNO}_{3}$ and $1 \mathrm{~mL}$ of concentrated $\mathrm{HCl}$ were added. This mixture was heated for $3 \mathrm{~h}$ at $85^{\circ} \mathrm{C}$ on a hot plate until the solubilization of the sample was complete and then diluted to $25 \mathrm{~mL}$ with deionized water in a polycarbonate volumetric flask. For $\mathrm{Hg}, 2.5 \mathrm{~g}$ MSW sample was digested separately by using aqua regia, potassium permanganate and sodium chloridehydroxylamie sulfate (USEPA 2007). Wet samples of MSW were used for analysis of $\mathrm{Cr}^{3+}$ and $\mathrm{Cr}^{6+}$. It was done to avoid the oxidation of trivalent $\mathrm{Cr}$ to its hexavalent state during drying of the samples. The proportions of $\mathrm{Cr}^{3+}$ and $\mathrm{Cr}^{6+}$ were determined following Rudel and Terytze (1999). A blank digest was carried out in the same way. All samples were analyzed three times for HM analysis.

Selective sequential extraction (SSE) of HMs in MSW in quadruplicate was carried out following Tessier et al. (1979). The SSE scheme was utilized to fractionate six pools of solid phase HMs. A sequential fractionation procedure was used to partition HMs into six fractions operationally defined as water soluble $\left(\mathrm{F}_{1}\right)$, exchangeable $\left(\mathrm{F}_{2}\right)$, acid soluble and bound to carbonates $\left(\mathrm{F}_{3}\right)$, reducible and bound to $\mathrm{Fe} / \mathrm{Mn}\left(\mathrm{F}_{4}\right)$, oxidizable/organic matter and sulfide bound $\left(\mathrm{F}_{5}\right)$ and residual/mineral matrix phase $\left(\mathrm{F}_{6}\right)$. The reagents used in the sequential extraction scheme were selected from those which are cited in the literature as being relatively selective for fractions of elements bound to different MSW components. For SSE, samples, each of $1 \mathrm{~g}$-aliquot, of MSW were weighted in $50 \mathrm{~mL}$ centrifugation tubes and extraction reagents were added sequentially. The following scheme was adopted: $\left(\mathrm{F}_{1}\right)$ deionized water in ratio $1: 10(\mathrm{w} / \mathrm{v}), 30-\mathrm{min}$ agitation at room temperature; $\left(\mathrm{F}_{2}\right) 40 \mathrm{~mL}$ of $1 \mathrm{M} \mathrm{MgCl}_{2}, \mathrm{pH} \mathrm{7,}$ 2-h agitation at room temperature; $\left(\mathrm{F}_{3}\right) 40 \mathrm{~mL}$ of $1 \mathrm{M} \mathrm{CH}_{3} \mathrm{COONa}(\mathrm{pH} 5), 5-\mathrm{h}$ agitation at room temperature; $\left(\mathrm{F}_{4}\right) 40 \mathrm{~mL}$ of $0.04 \mathrm{M}$ $\mathrm{NH}_{2} \mathrm{OH} \cdot \mathrm{HCl}$ in $25 \% \mathrm{CH}_{3} \mathrm{COOH}$, placed in a water bath at $96{ }^{\circ} \mathrm{C}$ for $6 \mathrm{~h}$; $\left(\mathrm{F}_{5}\right) 20 \mathrm{~mL}$ of $5.3 \% \mathrm{NaOCl}, \mathrm{pH} 8.5$, placed in a boiling water bath for $30 \mathrm{~min}$; $\left(\mathrm{F}_{6}\right) \mathrm{HClO}_{4}(2 \mathrm{~mL})$ and $\mathrm{HF}(10 \mathrm{~mL})$ to near dryness, followed by a second addition of $\mathrm{HClO}_{4}(1 \mathrm{~mL})$ and $\mathrm{HF}(10 \mathrm{~mL})$ and evaporation to near dryness; addition of $\mathrm{HC} \mathrm{O}_{4}(1 \mathrm{~mL})$ and evaporation until the appearance of white fumes; dissolution of the residue in $12 \mathrm{~N} \mathrm{HCl}$ and dilution to $25 \mathrm{~mL}$. MSW suspensions were agitated with a rotary shaker (Model No. Remi RSB-12, India) whenever required. After each extraction step, the tubes containing the MSW and the extractant were centrifuged for $15 \mathrm{~min}$ at $1,700 \times \mathrm{g}$ (Model No. Remi PR-24 centrifuge, India). The solution entrapped in the remaining mass was collected in subsequent wash steps and combined with the corresponding extracts. The final solutions were filtered through $0.45 \mu \mathrm{m}$ cellulose acetate filters and stored in polyethylene bottles. The residual MSW was used for the subsequent extraction steps. All extractions were performed in triplicate. Extracts which could not be analyzed immediately were stored at $4{ }^{\circ} \mathrm{C}$.

Analyses of $\mathrm{HMs}\left(\mathrm{Cd}, \mathrm{Cr}^{3+} / \mathrm{Cr}^{6+}, \mathrm{Cu}, \mathrm{Pb}, \mathrm{Zn}\right.$ and $\left.\mathrm{Ni}\right)$ were performed by atomic absorption spectrophotometer (AAS; VARIAN, Model No.: AA 240, Australia). Arsenic (As) and mercury ( $\mathrm{Hg}$ ) were determined using flow injection hydride generation atomic absorption spectrometry, FI-HG-AAS (Varian VGA 77 spectrophotometer, Australia) and cold vapor atomic absorption spectrometry, respectively. HM concentrations in MSW have been reported in the present investigation on dry weight basis.

Liquid sampling and analysis

Along with the MSW samples, run-off leachate from the dumpsite as well as surface water samples from Deepor Beel were collected. The leachate samples are described as LS: from the south corner, LN: from the north corner, LE: from the east corner and LW: from the west corner of the dumpsite. Similarly, water samples are described as 
DBW1: $1 \mathrm{~m}$ away from the dumpsite, DBW2: $20 \mathrm{~m}$ away, DBW3: $100 \mathrm{~m}$ away, DBW4: $1 \mathrm{~km}$ away and DBW5: $2 \mathrm{~km}$ away towards Deepor Beel. Since, the landfill site was not equipped with a leachate collector, the leachate was collected at the base of the landfill using $500 \mathrm{~mL}$ disposable plastic syringe. Collected leachate and water samples were transferred into sterile pre-cleaned (by nitric acid and Milli-Q water) $2.5 \mathrm{~L}$ brown sampling bottles and kept in an ice box. They were transported to the laboratory and immediately filtered with $0.45 \mu \mathrm{m}$ membrane by tangential flow ultra filtration method. The filtrated samples were stored in precleaned $2 \mathrm{~L}$ brown glass amber bottles below $4{ }^{\circ} \mathrm{C}$ until analysis. For HMs analysis, samples were collected separately and acidified with glacial acetic acid ( $0.5 \mathrm{~mL}$ per $100 \mathrm{ml}$ samples) followed by $0.2 \mathrm{~mL}$ formaldehyde per $100 \mathrm{~mL}$ of samples at the time of collection. Liquid samples were collected in a $300 \mathrm{~mL}$ biochemical oxygen demand (BOD) bottle, with minimum aeration. For bacteriological parameters, samples were collected in sterile $250 \mathrm{~mL}$ stopper glass bottle. The selected analyses, viz. $\mathrm{pH}$, alkalinity, total dissolved solids (TDS), electrical conductivity (EC), chloride $\left(\mathrm{Cl}^{-}\right)$, fluoride $\left(\mathrm{F}^{-}\right)$, BOD, $\mathrm{COD}$, total nitrogen $(\mathrm{TN})$, ammonium- $\mathrm{N}\left(\mathrm{NH}_{4}-\mathrm{N}\right)$, were started without delay, based on the priority to analyze parameters as prescribed by APHA (1995) methods. HMs ( $\mathrm{Zn}, \mathrm{Cu}, \mathrm{Cd}, \mathrm{Ni}, \mathrm{Cr}$ and $\mathrm{Pb}$ ), TCF and FCF were measured using standard methods (APHA 1995).

Vegetables sampling, pretreatments and analysis

During sampling, it was observed that some vegetables like ash gourd [Benincasa hispida (Thumb.) Cogn.], snake gourd (Trichosanthes anguina L.), stem amaranth (Amaranthus lividus L.) and eddoe [Colocasia schott (L.) Schott] growing naturally (from seeds dispersed either from the household or market wastes) adjoining the MSW dumping site (around 15-20 m) were often harvested, cooked and consumed by the rag pickers. Plant population on that site was found to be enough to satisfy the daily vegetables requirement for about 50 rag pickers. Only the edible part of each vegetable was used for analytical purposes. They were collected by hand using vinyl gloves, packed into polyethylene bags and weighed in situ. The cleaning (removal of soil) of samples was performed by shaking and in the case of eddoe by means of a dry pre-cleaned vinyl brush. The samples were weighed, washed with distilled water to eliminate air borne pollutants, dried in an oven at $65{ }^{\circ} \mathrm{C}$ for $24 \mathrm{~h}$, and then re-weighed to determine water content and ground to powder and used for the metal analysis. Visible contaminants were hand-picked from the vegetable samples. The leaves from amaranth plants were handpicked, and the non-edible parts of ash gourd, snake gourd and eddoe were removed using a plastic knife. The edible portions of vegetables were washed three times with distilled water and finally rinsed with deionised water and dried in an oven at $65{ }^{\circ} \mathrm{C}$, ground using a wooden grinder and analyzed to ascertain the presence of $\mathrm{HMs}$ (viz. $\mathrm{Zn}, \mathrm{Cd}, \mathrm{Cu}, \mathrm{Ni}, \mathrm{Pb}$ and $\mathrm{Cr})$. For the digestion of vegetables, $1.00 \mathrm{~g}$ of ground sample was placed in an Erlenmeyer flask, and $3 \mathrm{~mL}$ of concentrated $\mathrm{HNO}_{3}$ and $1 \mathrm{~mL}$ of concentrated $\mathrm{HCl}$ were added. This mixture was heated for $3 \mathrm{~h}$ at $85{ }^{\circ} \mathrm{C}$ on a hot plate until the solubilization of the sample was complete and then diluted to $25 \mathrm{~mL}$ with deionized water in a polycarbonate volumetric flask. A blank digest was carried out in the same way. All samples were analyzed three times for HM. Heavy metal concentrations in vegetables have been reported in the present investigation on dry weight basis.

Preparation of curry and analysis

To investigate the ingestion of HMs in human body through consumption of cooked vegetables grown in MSW dumping site, curry was prepared using those vegetables and was analyzed for HMs. Prior to curry preparation, all the said vegetables were thoroughly cleaned with distilled water. Thereafter, skin of ash gourd, snake gourd and eddoe were removed using a plastic knife and chopped into small pieces. Leaves from amaranth plants were used as it is consumed as a leafy vegetable. Stems of eddoe and fruits of ash gourd/snake gourd were used for the preparation of curry. Burned earthen pots are most commonly used by rag pickers for cooking in the present location and, therefore, were selected for this study. Four different curries were prepared using usual practice of rag pickers. A sample of $5 \mathrm{~g}$ of homogenous dried curry was used for metal analysis of each curry following the same procedure described for vegetables.

Normalization of the analyses and the data to international standards were set as follows: three standard reference materials (SRM), viz., SRM-2709 (San Joaquin Soil from the National Institute of Standards and Technology, Gaithersburg, MD 20899, USA), SRM-1645 (River Sediment from the National Bureau of Standards, Washington, DC 20234, USA) and SRM-1515 (apple leaves, National Institute of Standards and Technology, Japan) were utilized to verify the analytical results. SRMs were analyzed making use of the same procedures as was used for MSW samples. The findings were in agreement with the certified values.

Statistical analysis

The raw data were used for graphical Box-Whisker diagram. In order to analyze multiple inter-relationships among all the physico-chemical and bacterial variables, Pearson's correlation and principle component analysis (PCA) were carried out using the software SPSS 13.0. 


\section{Results and discussion}

Solid waste characteristics

The major identifiable components present in MSW1 (MSW collected from 0 to $1 \mathrm{~m}$ ) were $\mathrm{KW}(32.15 \%)$, paper $(12.24 \%)$, plastic $(12.25 \%)$ and textiles (12.24\%) followed by BMW (1.12\%), which is potentially hazardous from the bacteriological viewpoint. Plastic and soil were the major identifiable components (Fig. 2) in MSW2 (MSW collected from 1 to $2 \mathrm{~m}$ ) (26.98 and $28.0 \%$ ) and MSW3 (MSW collected from 2 to $3 \mathrm{~m}$ ) (31.52 and $39.0 \%)$.

\section{Physical and chemical properties of MSW}

The color of MSW1 (MSW collected from 0 to $1 \mathrm{~m}$ ) was mild reddish brown (5 year 4/3), whereas, MSW2 (MSW collected from 1 to $2 \mathrm{~m}$ ) and MSW3 (MSW collected from 1 to $3 \mathrm{~m}$ ) were intense reddish brown $(7.5$ year $4 / 4)$ and dark grey (5 year 4/1), respectively.

In MSW3, the moisture content was highest due to the accumulation of leachate produced by the biochemical degradation of MSW (Fig. 3a). The volatile solid (VS) decreased with an increase in the depth of sampling as the main reason appears to be the differences in soil contents among the MSW samples (Fig. 3b). Bulk density showed significant variation at all depths (Fig. 3c). A higher value of bulk density was observed in MSW2 which could be ascribed to the presence of high moisture and less plastic content. Highest amount of VS (42.1\%) was present in MSW1 which might have decreased the $\mathrm{pH}$ of this sample. Tchobanoglous et al. (1993) also reported a negative correlation between $\mathrm{VS}$ and $\mathrm{pH}$ due to the presence of fatty acids in VS. MSW1 and MSW3 were slightly acidic to neutral in reaction (Fig. 3d). However, the pH of MSW2 was found to be moderately alkaline with a value of 7.6. This $\mathrm{pH}$ value of MSW2 indicated the characteristic of waste to neutralize the organic acid that is either generated from the anaerobic degradation of organic matter (Prechthai et al. 2008) or may be influenced by the proteolyses occurring during the organic-matter degradation. EC was higher in MSW1 which indicated higher amount of soluble salts in the top layer of MSW (Fig. 3e) that subsequently decreased with an increase in the depth, due to difference in water contents of the MSW samples. Further, higher amount of $\mathrm{S}$ (total) and lower concentration of basic nitrogen (viz. $\mathrm{NH}_{4}{ }^{+}-\mathrm{N}$ ) also influenced the $\mathrm{pH}$ of MSW1 (Prechthai et al. 2008).

Clay content and cation exchange capacity (CEC) increased with an increase in the depth (Fig. 3f, g). The existence of total organic carbon (TOC) in MSW samples indicates the presence of biodegradable organic substances in the samples (Fig. 3h). In MSW1, humus carbon was found lower (Fig. 3i) probably due to the lack of optimum humification conditions (Prechthai et al. 2008). Humification is an oxygen-driven degradation and successive polymerization process occurring on organic carbon and it normally takes time. Further, the lower humus content in the upper layer (MSW1) may be attributed to the lower age of such a layer.
Fig. 2 Physical composition of solid waste in the MSW samples (BMW Biomedical waste, GTR Garden trimmings, $K W$ Kitchen wastes), A: MSW1 (MSW collected from 0 to $1 \mathrm{~m}$ depth); B: MSW2 (MSW collected from 1 to $2 \mathrm{~m}$ depth) and C:MSW3 (MSW collected from 2 to $3 \mathrm{~m}$ depth)
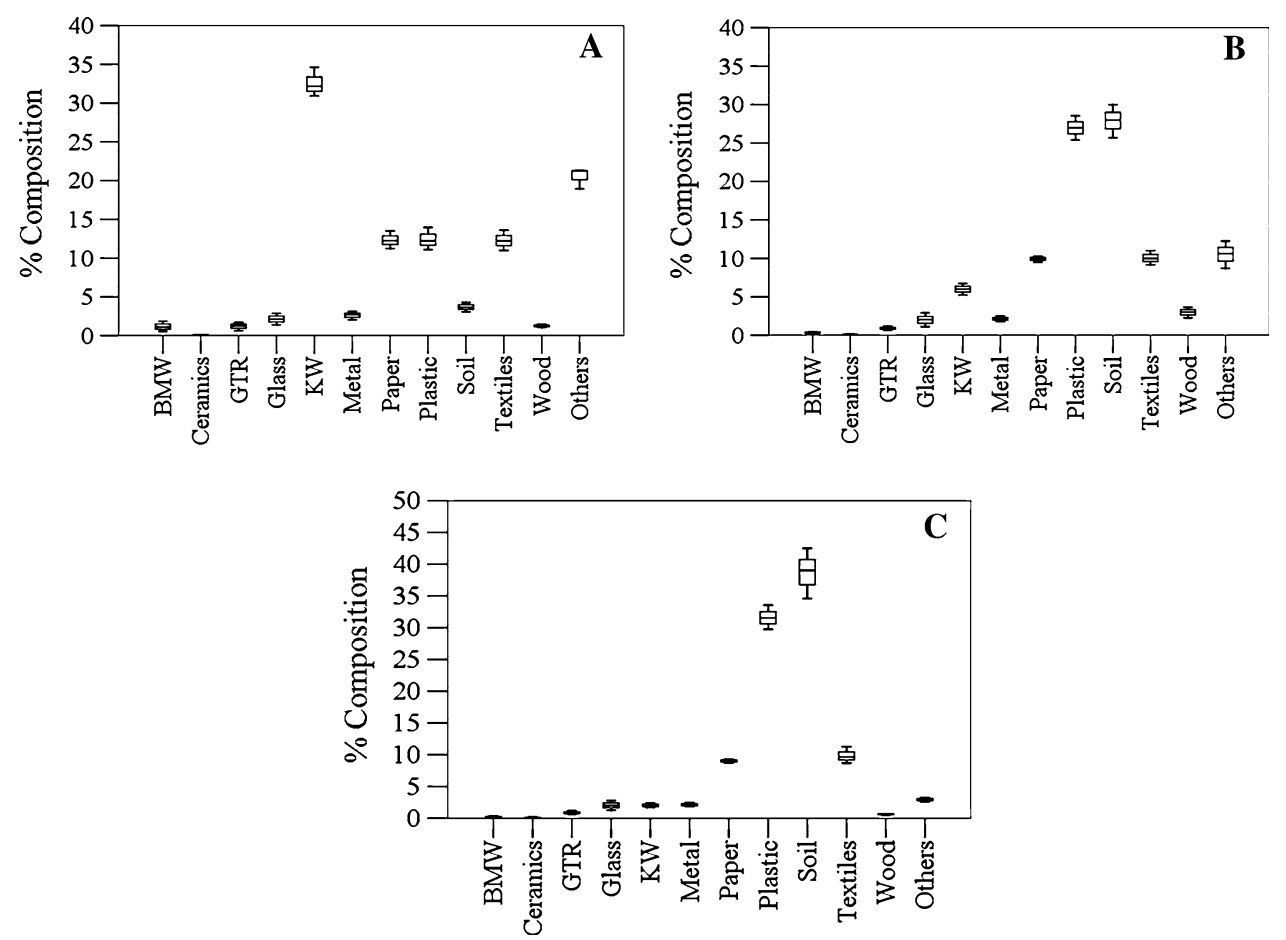

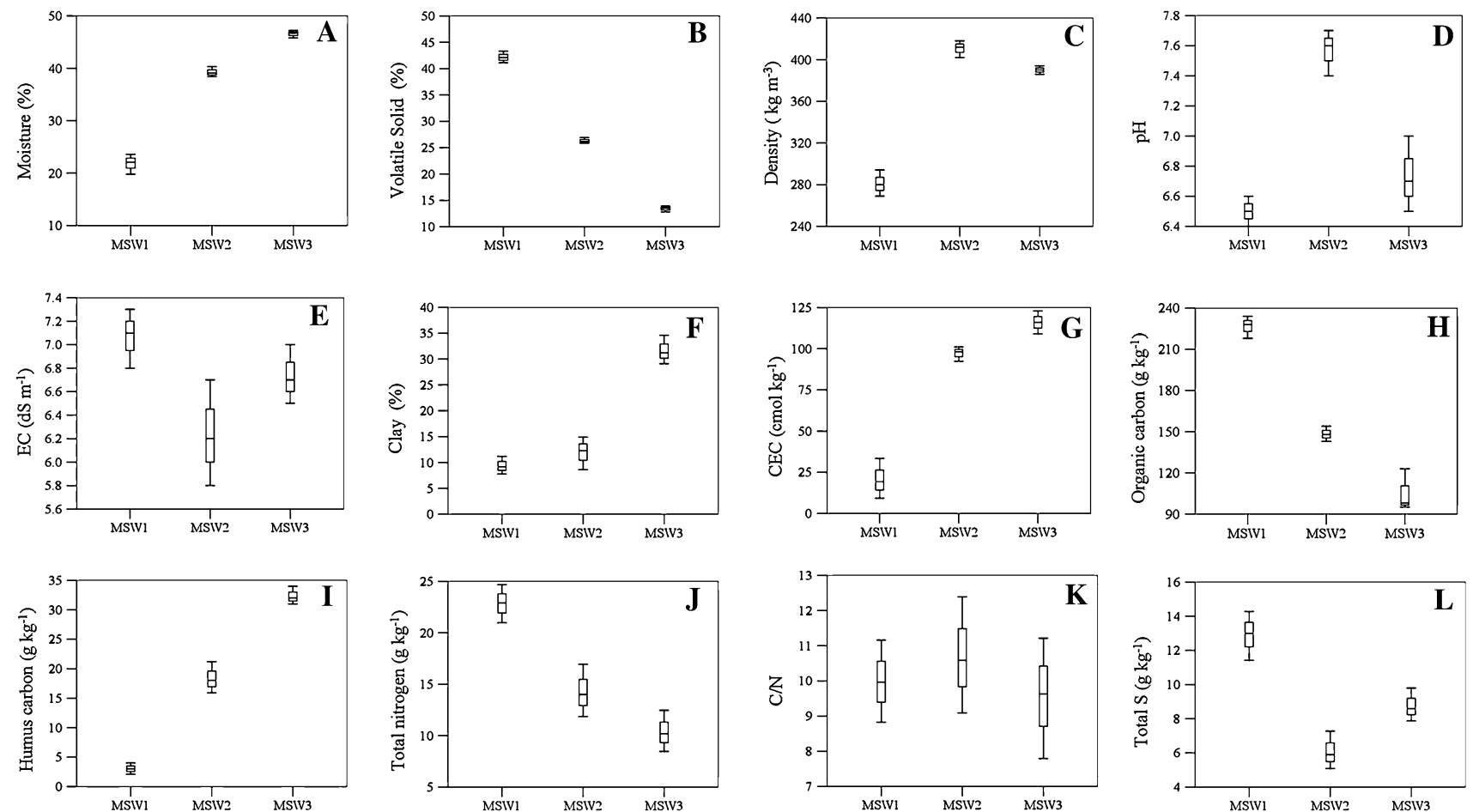

Fig. 3 Physical and chemical properties of MSW samples

TOC and TN (Fig. 3h, j) decreased significantly with an increase in the depth $(p<0.05)$. The $\mathrm{C} / \mathrm{N}$ ratio was 9.3-10.6 for MSW1, 9.9-11.5 for MSW2 and 8.7-10.3 for MSW3 (Fig. 3k) with a mean of 9.6, 10.6 and 9.8 for MSW1, MSW2 and MSW3, respectively. It also appears that the difference in $\mathrm{C} / \mathrm{N}$ between the MSW samples was not significant. No particular trend on total $\mathrm{S}$ was found among MSW samples (Fig. 31). From the physico-chemical properties of MSW samples, it is clear that MSW3 had the proposed standard of maturity of the compost, described by Epstein (1997). The color of MSW3 was dark gray (5 year 4/1) with smell like forest soil which can be considered as mature composts on its physical appearance (Epstein 1997). Furthermore, it is recognized worldwide that maturity of compost can be assessed by means of specific phytotoxicity tests, as that pointed out by Zucconi et al. (1981). Since this paper did not show any data on germination and/or plant growth test of MSW3, it is questionable that MSW3 can be considered as a "mature compost".

Selective heavy metals load in MSW

However, the application of MSW3 as compost in agricultural land is still questionable without verifying the HMs contents in it. Consequently, some selected HMs and their fractionations were proposed in the present investigation.
Among the selected HMs, Zn was most abundant followed by total $\mathrm{Cr}, \mathrm{Ni}, \mathrm{Cu}, \mathrm{Pb}$ and $\mathrm{Cd}$ (Fig. 4). In most cases, the concentration of HMs was found to increase with an increase in the depth. This is because under anaerobic condition and at greater depths, HMs were immobilized and retained in the solid waste (He et al. 2006).

It was observed that the HMs content in MSW3 exceeded the limits for $\mathrm{Cr}, \mathrm{Zn}$ and $\mathrm{Ni}$ (arsenic as $\mathrm{As}_{2} \mathrm{O}_{3}$ $10 \mathrm{mg} \mathrm{kg}^{-1}$, cadmium $5 \mathrm{mg} \mathrm{kg}^{-1}$, chromium $50 \mathrm{mg} \mathrm{kg}^{-1}$, copper $300 \mathrm{mg} \mathrm{kg}^{-1}$, mercury $0.15 \mathrm{mg} \mathrm{kg}^{-1}$, nickel $50 \mathrm{mg} \mathrm{kg}^{-1}$, lead $100 \mathrm{mg} \mathrm{kg}^{-1}$, zinc $1,000 \mathrm{mg} \mathrm{kg}^{-1}$ ) as recommended by the United States Environmental Protection Agency USEPA (1999) and the Central Pollution Control Board, India (CPCB) (Municipal Solid Wastes (Management and Handling) Rules 2000). Therefore, this result raises the doubts of sustainable utilization of MSW3 as compost in agricultural land. Besides, metal carrying wastes need to be approached with caution and concern because the prolonged application of MSW3 as compost in agricultural land is likely to increase the concentration of HMs in the soil with time even though MSW3 physically looks like mature compost. As and $\mathrm{Hg}$ contents in all the samples were below the detection limits of the instrument (0.01 mg L $\mathrm{mg}^{-1}$ for As and $550 \mathrm{ng} \mathrm{L}^{-1}$ for $\mathrm{Hg}$ ). Therefore, standard addition protocol was used and the $\mathrm{As}$ and $\mathrm{Hg}$ contents were determined again. However, $\mathrm{As}$ and $\mathrm{Hg}$ were not detected in any sample. 
Fig. 4 Concentrations of selected heavy metals in MSW samples
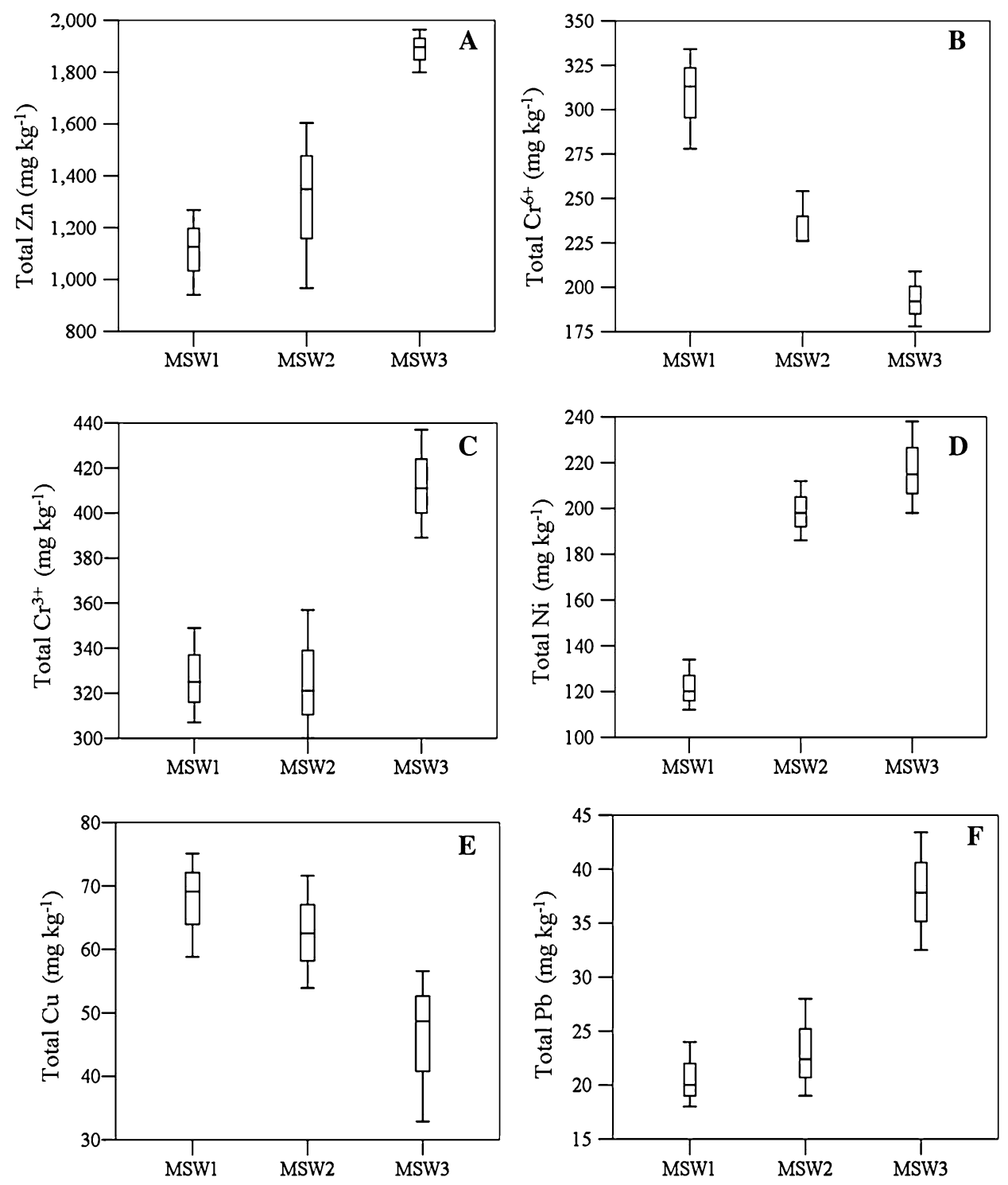

SSE of heavy metals in MSW

The percentages of recovery by SSE scheme were found to be between 82.5 and $98.5 \%$ (Table 1).

The intra-method reproducibility of the SSE procedure was convincing, with relative standard deviations of less

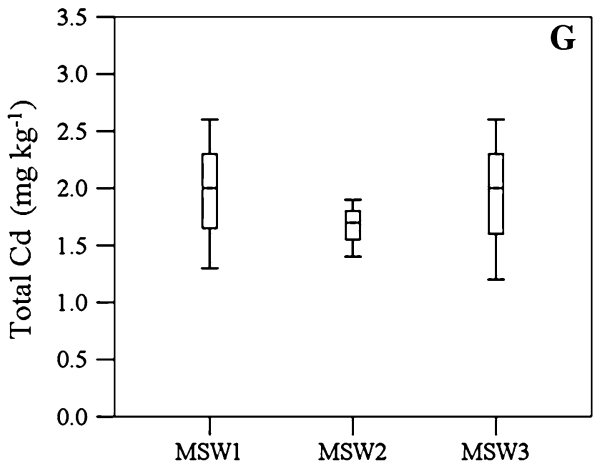

than $3 \%$ for all the fractions. The inter-method variability between the SSE and the acid digestion method was tested statistically using independent $t$ test which showed that using the $95 \%$ confidence interval, no significant difference was found between the sum of individual metal extracted from the SSE and the total individual metal 


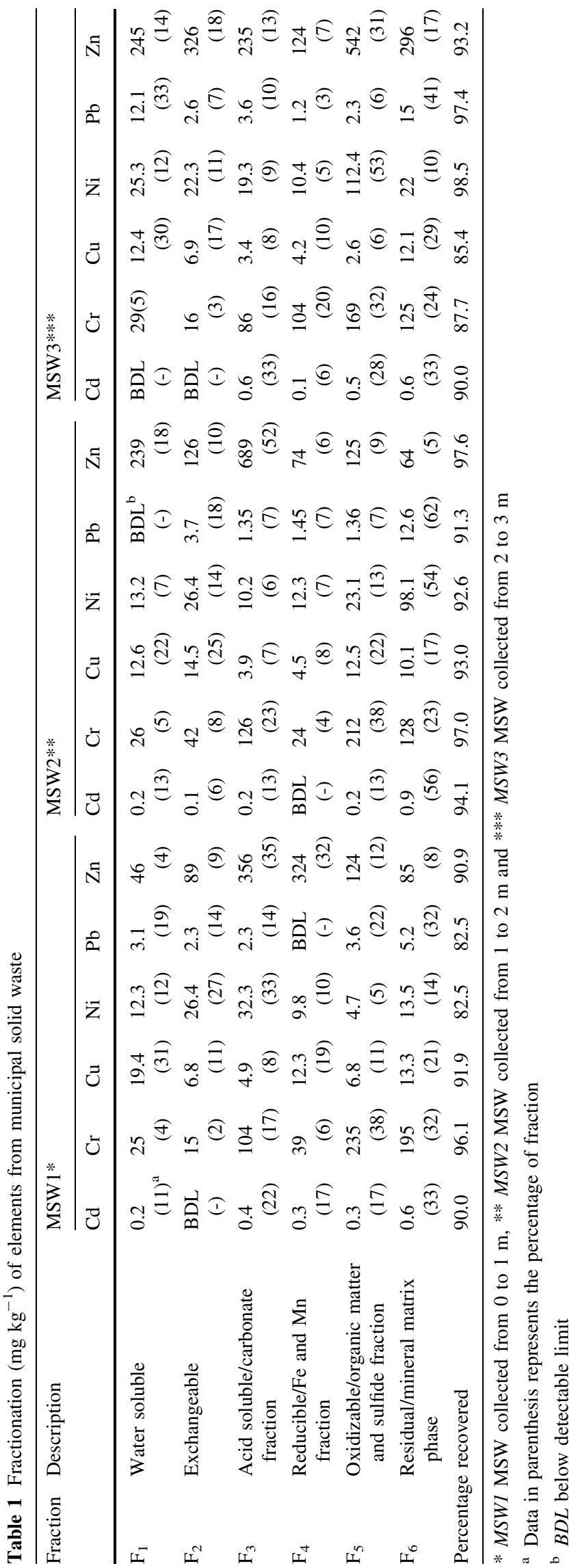

determined by the acid digestion method. The good reproducibility and low variability of the fractionation results demonstrated by the adopted SSE could be attributed to the uniformly contaminated MSW samples investigated in this study and the meticulous procedure followed in the SSE protocol.

There were significant amount of mobile $\mathrm{Cd}$ fractions in MSW1 and MSW2 samples. Around $94 \%$ of $\mathrm{Cd}$ was associated in $F_{3}, F_{5}$ and $F_{6}$ fractions in MSW3. Mobile fractions $\left(\mathrm{F}_{1}\right.$ and $\left.\mathrm{F}_{2}\right)$ of $\mathrm{Cd}$ were not detected in MSW3. The presence of significant concentration of $\mathrm{Cd}$ in insoluble fraction in deeper layer was due to the continuous anaerobic condition. These results bear the resemblance with the findings of Ostman et al. (2006). In an anaerobic landfill, presence of more fractions of residual form of $\mathrm{Cd}$ has also been reported by Xiaoli et al. (2007).

Total $\mathrm{Cr}$ is principally distributed between $\mathrm{F}_{5}$ and $\mathrm{F}_{6}$. For the MSW with greater sulfur content, $\mathrm{Cr}$ is more likely to be found in oxidizable fraction than in residual fraction, since it probably forms sulfides with this type of MSW (Fuentes et al. 2004). A perusal of data in Table 1 indicates that in the $F_{1}$ and $F_{2}$ fractions, $\mathrm{Cr}$ did not exceed $13 \%$ in any of the MSW samples. Fractions 1 and 2, supposedly the most potential mobile fractions, made up of 42,47 and $47 \%$ of total $\mathrm{Cu}$ extracted in MSW1, MSW2 and MSW3, respectively. In the other four fractions $\left(\mathrm{F}_{3}\right.$ to $\left.\mathrm{F}_{6}\right)$, the concentrations were 58, 53 and $53 \%$ in MSW1, MSW2 and MSW3, respectively. A fairly low percentage of $\mathrm{Cu}$ was retained in $\mathrm{F}_{3}$. This fraction of $\mathrm{Cu}$ was bound to presumably highly amorphous iron oxyhydroxides and was extracted with proton dissolution and $\mathrm{Fe}-\mathrm{Cl}$ complexation as indicated by Keon et al. (2001).

$\mathrm{Ni}$ was widely distributed in all the fractions irrespective of the sampling depths. The sum of the first three fractions was approximately $72 \%$ in MSW 1 . Only $5 \% \mathrm{Ni}$ was extracted from $\mathrm{F}_{5}$ fraction in MSW1, probably due to the slow decomposition and the presence of low humus carbon in the upper layer. High amount of $\mathrm{Ni}$ in $\mathrm{F}_{3}$ fraction might be due to the lower $\mathrm{pH}$ in MSW1. Ni was extracted in large quantities from $\mathrm{F}_{6}$ fraction (54\% extraction) in MSW2, where $\mathrm{Ni}$ is bound to residual or mineral matrix phase. In MSW3, about $53 \%$ of $\mathrm{Ni}$ was extracted from the $\mathrm{F}_{5}$ fraction. Higher amount of Ni in MSW3 is characterized by high humus carbon. Humus carbon in MSW3 may have significant influence on the environmental mobility and bioavailability of $\mathrm{Ni}$ due to the formation of soluble aqueous complexes, stationary coatings on MSW mineral surfaces, aggregates and mobile colloidal phases. The high degree of $\mathrm{Ni}$ in $\mathrm{F}_{5}$ fraction has also been reported by Alonso et al. (2002).

The largest fraction of $\mathrm{Pb}$ was found in the residual form. It was not found in $F_{4}$ fraction of MSW1 and $F_{1}$ fraction of MSW2. After $\mathrm{F}_{6}$ fraction, $\mathrm{F}_{1}$ fraction of $\mathrm{Pb}$ was 
found in significant amount in MSW3. The $F_{1}$ fraction is generally considered as an immediate nutrient reservoir for plants (Narwal and Singh 1998; Bhattacharyya et al. 2008b). Therefore, presence of high water soluble fraction in MSW3 may be the potential source of $\mathrm{Pb}$ contamination in soil and consequently to plants.

The order of $\mathrm{Zn}$ concentration was $\mathrm{F}_{3}>\mathrm{F}_{4}>\mathrm{F}_{5}$ $>\mathrm{F}_{2}>\mathrm{F}_{6}>\mathrm{F}_{1}$ in MSW1, $\mathrm{F}_{3}>\mathrm{F}_{1}>\mathrm{F}_{2}>\mathrm{F}_{5}>\mathrm{F}_{4}>\mathrm{F}_{6}$ in MSW2 and $\mathrm{F}_{6}>\mathrm{F}_{2}>\mathrm{F}_{5}>\mathrm{F}_{1}>\mathrm{F}_{3}>\mathrm{F}_{4}$ in MSW3, respectively. In all MSW samples, the $\mathrm{Zn}$ solubility was limited by the formation of insoluble $\mathrm{Zn}$ compounds (or complexes), as implied by the high fraction of $\mathrm{Zn}$ associated with the insoluble fractions. The presence of acid soluble/carbonate fraction $\left(\mathrm{F}_{3}\right)$ and reducible/Fe and $\mathrm{Mn}$ fractions $\left(\mathrm{F}_{4}\right)$ in MSW1 and $\mathrm{F}_{3}$ fraction in MSW2 shows the prevailing high redox potential at these locations. High amount of oxidizable/organic matter and sulfide fraction $\left(\mathrm{F}_{5}\right)$ of $\mathrm{Zn}$ in MSW3 shows the prevailing low redox potential at this location. This can be attributed to the tendency of $\mathrm{Zn}$ to get absorbed in humus carbon, as MSW3 was in highly decomposed form. In an anaerobic landfill, presence of more fractions of oxidizable form of $\mathrm{Zn}$ was reported by Xiaoli et al. (2007). This result also reflects the findings of Alonso et al. (2002).

\section{Leachate and water characteristics}

The characteristics of leachate and surface water are shown in Table 2. All the leachates were black in color, with high level of TDS, and had a strong odor. Colors of water samples from DBW1 to DBW3 were black to slight brown. However, water samples collected beyond DBW3 were colorless, reflecting the mixing and contamination of Deepor Beel with dumpsite leachate. All leachate samples were slightly acidic to neutral thereby indicating a reducing environment in the dumpsite, which was in agreement with the observations made by Oygard et al. (2007). Water samples collected from the Deepor Beel were neutral to slightly alkaline. High alkalinity in all the leachate samples confirmed the methanogenic (is the formation of methane by microbes; Thauer 1998) condition of the dumpsite (Ehrig 1983). Recently, He et al. (2005) reported that high alkalinity levels (i.e., the methane alkalinity) of MSW leachate could be attributable to the rapid development of methanogen bacteria (see later).

Chloride $\left(\mathrm{Cl}^{-}\right)$in leachate samples varied between 1,239 and $3,625 \mathrm{mg} \mathrm{L}^{-1}$. Concentration of $\mathrm{Cl}^{-}$was found to be lower in water samples than in leachate samples. A close correlation between the $\mathrm{Cl}^{-}$and conductivity was observed in all the samples. This reflects that $\mathrm{Cl}^{-}$played a significant role in enhancing the conductivity. Fluoride $\left(\mathrm{F}^{-}\right)$in leachates varied from 2.98 to $24.39 \mathrm{mg} \mathrm{L}^{-1}$. However, $\mathrm{F}^{-}$content in water samples except DBW1 was within the prescribed safe limits of Bureau of Indian Standards (BIS 1999) and WHO (1997). Due to the severity of impacts of the excess fluoride in groundwater, the WHO permissible limit of fluoride in India has been reduced from 1.5 to $1.0 \mathrm{mg} \mathrm{L}^{-1}$ in 1998 (UNICEF 1999). Nevertheless, the continuous mixing of leachate from MSW could be a potential threat to the Deepor Beel and, therefore, there is an urgent need to take ameliorative steps to avoid further contamination.

Very high values of BOD $\left(11,000-52,000 \mathrm{mg} \mathrm{L}^{-1}\right)$ and COD (17,000-91,000 $\left.\mathrm{mg} \mathrm{L}^{-1}\right)$ were recorded in the leachates which were in agreement with the observations made by different researchers (Reinhart and Al-Yousfi 1996; Chian and DeWalle 1976; Lo 1996; Ozturk et al. 2003; Robinson 2005). BOD/COD ratio in leachate was $0.45-0.65$ which indicated a high portion of organic matter in the leachate as also observed by Hogland and Marques (2003), which also caused odor problems (Doedens and Cord-Landwehr 1989) in the study area. Lower ratio of BOD/COD (0.05-0.39) in water samples indicated lower organic matter in water.

The evaluation of $\mathrm{TN}$ and $\mathrm{NH}_{4}-\mathrm{N}$ in leachate samples indicated that most of the nitrogen was in the form of ammonia. It was possibly due to the degradation of proteins and amino acids present in MSW (Kjeldsen et al. 2002). These results corroborates with the findings of Ehrig and Scheelhaase (1993). Considerable amounts of HMs were found in the leachates. Zn was the most abundant element followed by $\mathrm{Cr}, \mathrm{Cu}$ and $\mathrm{Pb}$. This might be due to the complexation of these metals with dissolved organic compounds generated from degradation of the organic matter. Of all the metals, the concentrations of $\mathrm{Ni}$ and $\mathrm{Cd}$ were found less. The high metal load in all leachates suggests that sulfur content in MSW was insufficient to precipitate all the metals present. Low solubility product of Cd-sulfide $\left(1.4 \times 10^{-29}\right)$ (Weast et al. 1985), therefore, partly explains the relatively low level of $\mathrm{Cd}$ in the leachate. However, the concentration of all the HMs in the leachate was higher than the national effluent standards (0.01, 0.10, 0.20, 0.20, 5.0 and $2.0 \mu \mathrm{g} \mathrm{L}^{-1}$ for $\mathrm{Cd}, \mathrm{Cr}, \mathrm{Cu}$, $\mathrm{Ni}, \mathrm{Pb}$ and $\mathrm{Zn}$, respectively; BIS 1999).

Significant amount of HMs were also found in water samples of DBW1. The metal load in water samples decreased with an increase in sampling distance from the dumpsite. Therefore, dumping of MSW in a landfill for longer duration and the subsequent leaching of metals can cause severe damage to water bodies lying in close vicinity of MSW dumping site. This observation also corroborates Flyhammar et al. (1998) who reported that about $30 \%$ of the metal content in MSW deposited at a landfill was available for leaching.

Table 2 shows the presence of TCF and FCF in all samples, indicating the contamination of surface water 
Table 2 Physical, chemical and bacteriological parameters in MSW leachate and water samples collected from Deepor Beel

\begin{tabular}{|c|c|c|c|c|c|c|c|c|c|}
\hline \multirow[t]{2}{*}{ Parameters } & \multicolumn{4}{|c|}{ Leachate } & \multicolumn{5}{|l|}{ Water } \\
\hline & LS & $\mathrm{LN}$ & $\mathrm{LE}$ & LW & DBW1 & DBW2 & DBW3 & DBW4 & DBW5 \\
\hline Color & Black & Black & Black & Black & Black & Black & Light brown & Colorless & Colorless \\
\hline $\mathrm{pH}$ & 6.5 & 6.2 & 6.5 & 6.8 & 8.1 & 7.6 & 6.9 & 6.6 & 6.9 \\
\hline Alkalinity $\left(\mathrm{mg} \mathrm{L}^{-1}\right)$ & 64 & 92 & 81 & 52 & 130 & 120 & 84 & 72 & 91 \\
\hline TDS $\left(\mathrm{mg} \mathrm{L}^{-1}\right)$ & 2,000 & 1,200 & 956 & 1,422 & 1,391 & 264 & 212 & 76 & 52 \\
\hline $\mathrm{EC}\left(\mathrm{mS} \mathrm{m}^{-1}\right)$ & 912 & 620 & 262 & 815 & 728 & 128 & 98 & 25 & 12 \\
\hline $\mathrm{Cl}^{-}\left(\mathrm{mg} \mathrm{L}^{-1}\right)$ & 3,625 & 1,274 & 1,239 & 2,400 & 68 & 53 & 48 & 12 & 6 \\
\hline $\mathrm{F}^{-}\left(\mathrm{mg} \mathrm{L}^{-1}\right)$ & 2.98 & 12.13 & 24.39 & 16.52 & 1.96 & 0.39 & 0.12 & $\mathrm{BDL}^{\mathrm{a}}$ & 0.37 \\
\hline $\mathrm{BOD}\left(\mathrm{mg} \mathrm{L}^{-1}\right)$ & 22,000 & 11,000 & 14,000 & 52,000 & 125 & 98 & 0.6 & 2.4 & 0.6 \\
\hline $\mathrm{COD}\left(\mathrm{mg} \mathrm{L}^{-1}\right)$ & 48,800 & 17,000 & 29,000 & 91,000 & 800 & 252 & 9.3 & 29.2 & 13.28 \\
\hline $\mathrm{BOD} / \mathrm{COD}$ & 0.451 & 0.647 & 0.483 & 0.571 & 0.156 & 0.389 & 0.065 & 0.082 & 0.045 \\
\hline $\mathrm{TN}\left(\mathrm{mg} \mathrm{L}^{-1}\right)$ & 320 & 280 & 298 & 312 & 87 & 12 & 5 & 6 & 3 \\
\hline $\mathrm{NH}_{\mathrm{a}}-\mathrm{N}\left(\mathrm{mg} \mathrm{L}^{-1}\right)$ & 221 & 162 & 229 & 214 & 5.3 & 1.2 & 0.2 & 0.3 & 0.1 \\
\hline $\mathrm{Zn}\left(\mu \mathrm{g} \mathrm{L}^{-1}\right)$ & 125 & 871 & 512 & 264 & 1.26 & 0.527 & 0.126 & 0.221 & 0.359 \\
\hline $\mathrm{Cd}\left(\mu \mathrm{g} \mathrm{L}^{-1}\right)$ & 5.20 & 2.36 & 1.98 & 1.23 & 0.11 & 0.02 & $\mathrm{BDL}$ & BDL & BDL \\
\hline $\mathrm{Pb}\left(\mu \mathrm{g} \mathrm{L}^{-1}\right)$ & 53 & 61 & 28 & 56 & 2.13 & 0.56 & 0.09 & BDL & BDL \\
\hline $\mathrm{Cu}\left(\mu \mathrm{g} \mathrm{L}^{-1}\right)$ & 33 & 220 & 125 & 85 & 0.02 & BDL & BDL & BDL & BDL \\
\hline $\mathrm{Ni}\left(\mu \mathrm{g} \mathrm{L}^{-1}\right)$ & 0.12 & 0.36 & 0.49 & 0.19 & 0.09 & BDL & BDL & BDL & BDL \\
\hline $\mathrm{Cr}\left(\mu \mathrm{g} \mathrm{L}^{-1}\right)$ & 360 & 259 & 524 & 205 & 9.36 & 1.49 & $\mathrm{BDL}$ & BDL & BDL \\
\hline $\mathrm{TCF}^{\mathrm{b}}\left(\mathrm{MPN}^{\mathrm{c}} / 100 \mathrm{~mL}\right)$ & 93,000 & 28,000 & 75,000 & 43,000 & 21,000 & 1,500 & 1,100 & 1,100 & 1,100 \\
\hline $\mathrm{FCF}^{\mathrm{d}}(\mathrm{MPN} / 100 \mathrm{~mL})$ & 43,000 & 15,000 & 7,000 & 9,100 & 2,800 & 730 & 300 & 300 & 300 \\
\hline
\end{tabular}

${ }^{\mathrm{a}} B D L$ below detectable limit; ${ }^{\mathrm{b}}$ total coliforms, ${ }^{\mathrm{c}} M P N$ most probable number, ${ }^{\mathrm{d}}$ fecal coliforms

possibly due to leachate percolation. Water samples from DBW3, DBW4 and DBW5 showed less contamination with coliforms. The concept of coliforms as bacterial indicator of microbial water quality is based on the premise that coliforms are present in high numbers in the feces of human and other warm-blooded animals. If fecal pollution enters into the surface water, it is likely that these bacteria will be present there, even after significant dilution. The presence of fecal contamination is an indicator that a potential health risk exists for an individual exposed to this water. The coliform bacteria can multiply when leachate enters into an oxygenated system. Neill (2004) found that when leachate was diluted with the bacteria-free freshwater then there was an increase in the number of thermotolerant coliforms. Nonetheless, this water is unfit for domestic consumption as BOD and HMs load exceeded the limits prescribed by Bureau of Indian Standards (BIS 1999).

Assessment of heavy metals in fresh vegetables

Increasing metal concentrations and changes in their distribution in MSW generally increased the concentrations of HMs in the tissues of plants growing on the MSW dumping site. The trends of HMs among the different vegetables were $C$. schott $\left(120.4 \mu \mathrm{g} \mathrm{g}^{-1}\right)>B$. hispida $\left(106.2 \mu \mathrm{g} \mathrm{g}^{-1}\right)>T$. anguina $\left(75.3 \mu \mathrm{g} \mathrm{g}^{-1}\right)>A$. lividus $\left(60.3 \mu \mathrm{g} \mathrm{g}^{-1}\right)$ for $\mathrm{Zn} ;$ C. schott $\left(\mathrm{Cd}: 1.10 \mu \mathrm{g} \mathrm{g}^{-1} ; \mathrm{Pb}: 3.21\right.$ $\left.\mu \mathrm{g} \mathrm{g}^{-1}\right)>T$. anguina ( $\mathrm{Cd}: 0.09 \mu \mathrm{g} \mathrm{g}^{-1} ; \mathrm{Pb}: 2.3 \mu \mathrm{g} \mathrm{g}^{-1}$ ) $>$ B. hispida $\left(\mathrm{Cd}: 0.03 \mu \mathrm{g} \mathrm{g}^{-1} ; \mathrm{Pb}: 1.9 \mu \mathrm{g} \mathrm{g}^{-1}\right)>$ A. lividus (Cd: $0.01 \mu \mathrm{g} \mathrm{g}^{-1}$; $\mathrm{Pb}: 0.9 \mu \mathrm{g} \mathrm{g}^{-1}$ ) for $\mathrm{Cd}$ and $\mathrm{Pb}$; C. schott (Ni: $\left.0.64 \mu \mathrm{g} \mathrm{g}^{-1} ; \mathrm{Cu}: 7.9 \mu \mathrm{g} \mathrm{g}^{-1}\right)>B$. hispida (Ni: $\left.\quad 0.29 \mu \mathrm{g} \mathrm{g}^{-1} ; \quad \mathrm{Cu}: \quad 5.9 \mu \mathrm{g} \mathrm{g}^{-1}\right)>A$. lividus (Ni: $0.11 \mu \mathrm{g} \mathrm{g}^{-1} ; \mathrm{Cu}: 3.6 \mu \mathrm{g} \mathrm{g}^{-1}$ ) $>T$. anguina (Ni: $\left.0.06 \mu \mathrm{g} \mathrm{g}^{-1} ; \mathrm{Cu}: 2.9 \mu \mathrm{g} \mathrm{g}^{-1}\right)$ for $\mathrm{Ni}$ and $\mathrm{Cu}$ and $C$. schott $\left(0.13 \mu \mathrm{g} \mathrm{g}^{-1}\right)>A$. lividus $\quad\left(0.04 \mu \mathrm{g} \mathrm{g}^{-1}\right)>B$. hisp$i d a=T$. anguina $\left(0.01 \mu \mathrm{g} \mathrm{g}^{-1}\right)$ for $\mathrm{Cr}$. Among all the vegetables, $C$. schott accumulated higher amount of HMs. It was observed that below the ground portion of all the vegetable crops did not exceed $1 \mathrm{~m}$. Therefore, the probable reason for the accumulation of HMs by different vegetables might be the presence of mobile phase of HMs in MSW1 (Table 1). The Cd levels obtained in the present study varied between 0.01 and $1.10 \mu \mathrm{g} \mathrm{g}^{-1}$, which were much higher than that in Indian vegetables (0.0032-0.0149 $\mu \mathrm{g} \mathrm{g}^{-1}$ ) as reported by Tripathi et al. (1997) and also in vegetables from UK as reported by Ysart et al. (1999). Among all the four vegetables, $C$. schott (where its tuber is consumed as vegetable) accumulated high amount of $\mathrm{Cr}$ $\left(0.13 \mu \mathrm{g} \mathrm{g}^{-1}\right)$. The probable reason for its higher accumulation might be its greater sequestration capacity in soluble forms in the vacuoles of the root (Adriano 1986). The concentration of $\mathrm{Cu}$ in vegetables growing on MSW 
dumping site ranged from 2.9 to $7.9 \mu \mathrm{g} \mathrm{g}^{-1}$ which was higher as compared to that in other parts of India (Tripathi et al. 1997). The Ni contents in all vegetable samples collected from MSW dumping site were low (0.06 to $0.64 \mu \mathrm{g} \mathrm{g}^{-1}$ ). Except A. lividus significant amount of $\mathrm{Pb}$ was uptaken by all other vegetables. $\mathrm{Pb}$ concentrations in green vegetables studied were higher as compared to vegetables studied in UK (Ysart et al. 1999) and India (Tripathi et al. 1997). Among the metals analyzed, Zn was relatively labile and readily transferred to plant tissues (Table 1). Zn uptake was greater for $C$. schott and $B$. hispida as compared to other vegetables. The $\mathrm{Zn}$ obtained in the present study was much higher than in other Indian vegetables as reported by Tripathi et al. (1997).

Heavy metal ingestion through diet

The vegetables grown in the experimental site are usually taken by rag pickers and are consumed after cooking. In Indian conditions, WHO (1993) recommended approximately $190 \mathrm{~g}$ of per capita consumption of fresh vegetables. Therefore, $190 \mathrm{~g}$ of vegetables was cooked by standard Indian preparation procedure (described in materials and methods section). No heavy metal was found in other ingredients used to prepare the dish/vegetables.

No significant difference in the metal concentrations between cooked and uncooked vegetables was recorded which indicates that the loss of metals during cooking was insignificant. The intake of HMs depended on the relative amounts of the vegetable compositions. The trend of total HMs intake was found as 1:1:1:1 $(18549.28 \mu \mathrm{g} / 190 \mathrm{~g}$ fresh vegetables $)>3: 2: 2: 1 \quad(17915.23 \mu \mathrm{g} / 190 \mathrm{~g}$ fresh vegetables) $>1: 2: 1: 1 \quad(17767.50 \mu \mathrm{g} / 190 \mathrm{~g}$ fresh vegetables $)>$ 1:2:2:1 $(16828.67 \mu \mathrm{g} / 190 \mathrm{~g}$ fresh vegetables). The HMs intake in all the vegetables was in the order of
$\mathrm{Zn}>\mathrm{Cu}>\mathrm{Pb}>\mathrm{Cd} \approx \mathrm{Ni}>\mathrm{Cr}$ (Table 3). Although, the daily intake of HMs from prepared food did not exceed the permissible limit prescribed $(\mathrm{Cd}, \mathrm{Cr}, \mathrm{Cu}, \mathrm{Ni}, \mathrm{Pb}$, and $\mathrm{Zn}$ as $0.21,0.02,3.00,1.63,0.43$ and $27.4 \mu \mathrm{g} \mathrm{g}^{-1}$ on dry weight basis for consumption) by WHO (1993) and by Indian Council of Medical Research (ICMR 2001), it provided a significant additional source of HM consumption from the diet prepared out of the vegetables.

\section{Statistical analysis}

In this study, the exploratory data analysis techniques have been applied to datasets on physico, chemical and bacteriological properties and the results obtained are highlighted. The ranges of variation, mean and standard deviation and the variation of parameters with their standard error are shown by the box plots. There was a significant positive correlation of HMs (except $\mathrm{Cr}^{6+}$ ) with clay particles and humus-C in the MSW samples (Table 4). According to data reported in Table 4, the positive correlation of HMs (analyzed) with clay and humus-C was significant only for $\mathrm{Zn}, \mathrm{Ni}, \mathrm{Cr}^{3+}$ and $\mathrm{Pb}$. Thus, the interaction between humus-C and HMs explains the distribution of HMs in MSW.

Pearson's correlation between physico-chemical-bacteriological parameters in liquid samples (leachate from dumping site + water from Deepor Beel) revealed a significant negative correlation of $\mathrm{HMs}$ with $\mathrm{pH}$ and alkalinity perhaps due to the fact that high $\mathrm{pH}$ decreases $\mathrm{HM}$ concentrations in water samples due to the precipitation of the metals as hydroxides and carbonates (Table 5). According to data reported in Table 5, the negative correlation of $\mathrm{HMs}$ with alkalinity was not significant for $\mathrm{Zn}, \mathrm{Cu}$ and $\mathrm{Ni}$.

Principal component analysis (PCA) is one of the best statistical techniques for extracting linear relationships

Table 3 Heavy metal concentrations in cooked dish prepared from fresh vegetables growing on the MSW dumpsite

\begin{tabular}{|c|c|c|c|c|c|c|}
\hline \multirow{2}{*}{$\begin{array}{l}\text { Proportion of the amounts of vegetables by weight in cooked food } \\
\text { Ash gourd:snake gourd:stem amaranth:eddoe }\end{array}$} & \multicolumn{6}{|c|}{ Metal concentration $(\mu \mathrm{g} / 190 \mathrm{~g}$ fresh vegetables) in cooked food } \\
\hline & $\mathrm{Cd}$ & $\mathrm{Cr}$ & $\mathrm{Cu}$ & $\mathrm{Ni}$ & $\mathrm{Pb}$ & $\mathrm{Zn}$ \\
\hline 1:1:1:1 & $\begin{array}{l}56.32 \\
(58.43)^{\mathrm{a}}\end{array}$ & $\begin{array}{l}8.19 \\
(9.03)\end{array}$ & $\begin{array}{l}959.25 \\
(964.25)\end{array}$ & $\begin{array}{l}49.15 \\
(52.25)\end{array}$ & $\begin{array}{l}312.25 \\
(394.25)\end{array}$ & $\begin{array}{l}17,164.12 \\
(17,204.50)\end{array}$ \\
\hline $1: 2: 1: 1$ & $\begin{array}{l}42.08 \\
(44.08)\end{array}$ & $\begin{array}{l}7.08 \\
(7.60)\end{array}$ & $\begin{array}{l}865.58 \\
(881.60)\end{array}$ & $\begin{array}{l}42.14 \\
(44.08)\end{array}$ & $\begin{array}{l}385.62 \\
(402.80)\end{array}$ & $\begin{array}{l}16,425.00 \\
(16,625.00)\end{array}$ \\
\hline $1: 2: 2: 1$ & $\begin{array}{l}40.09 \\
(42.12)\end{array}$ & $\begin{array}{l}6.26 \\
(7.60)\end{array}$ & $\begin{array}{l}960.75 \\
(973.75)\end{array}$ & $\begin{array}{l}46.26 \\
(50.35)\end{array}$ & $\begin{array}{l}352.17 \\
(364.17)\end{array}$ & $\begin{array}{l}15,423.14 \\
(15,763.67)\end{array}$ \\
\hline $3: 2: 2: 1$ & $\begin{array}{l}74.05 \\
(80.05)\end{array}$ & $\begin{array}{l}5.58 \\
(6.18)\end{array}$ & $\begin{array}{l}908.75 \\
(916.75)\end{array}$ & $\begin{array}{l}40.39 \\
(43.94)\end{array}$ & $\begin{array}{l}309.37 \\
(363.38)\end{array}$ & $\begin{array}{l}16,577.09 \\
(16,867.25)\end{array}$ \\
\hline
\end{tabular}

\footnotetext{
${ }^{a}$ Figures in parenthesis represent the metal content in uncooked vegetables (190 g)
} 


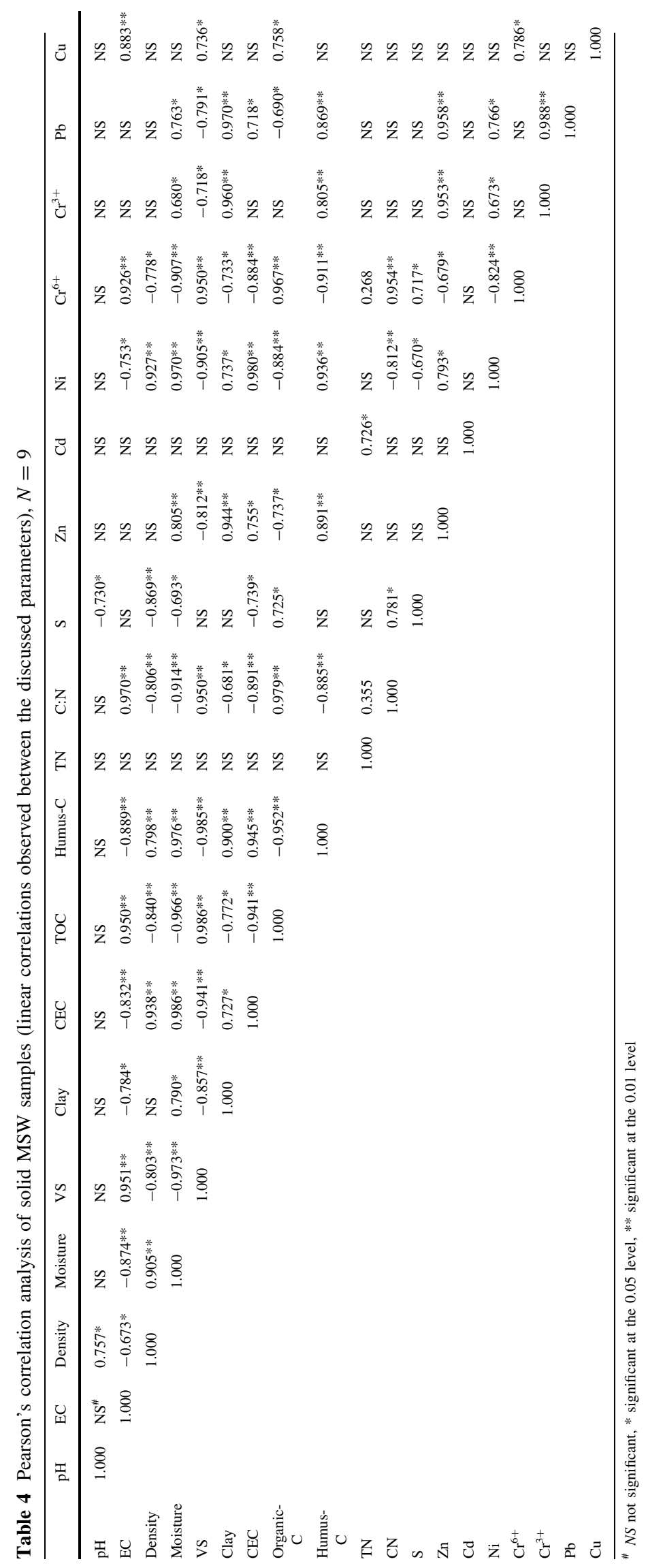




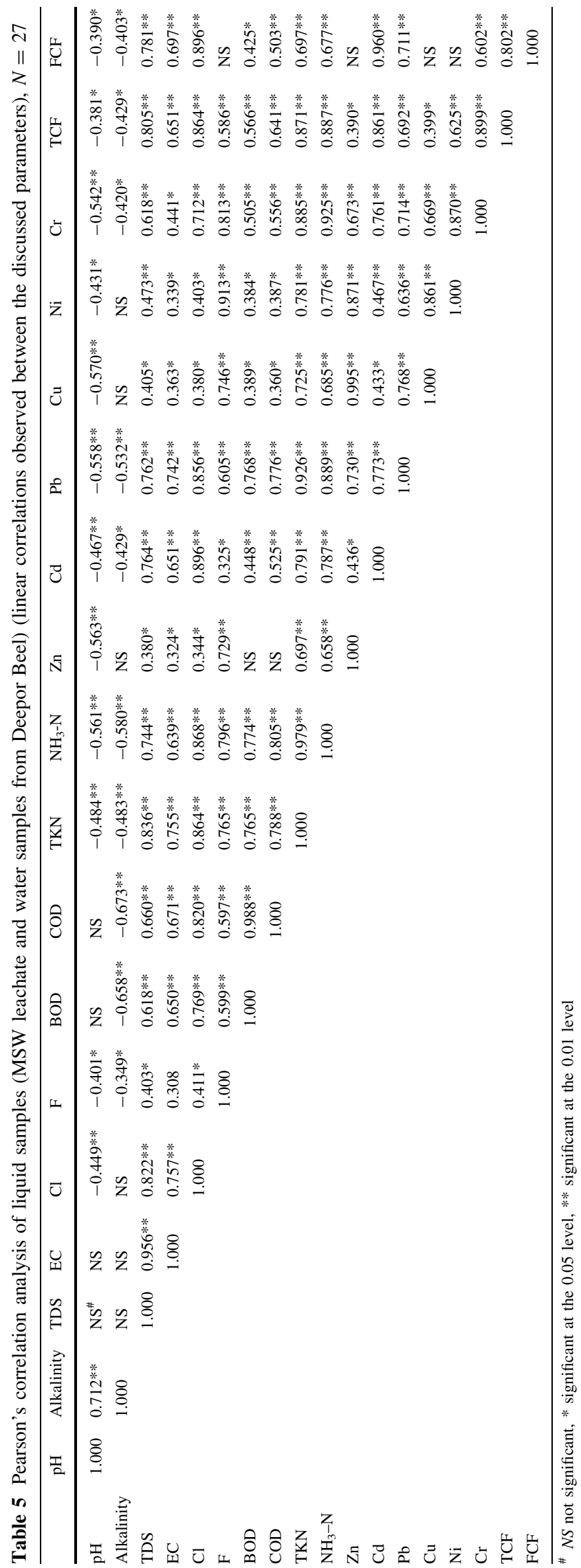



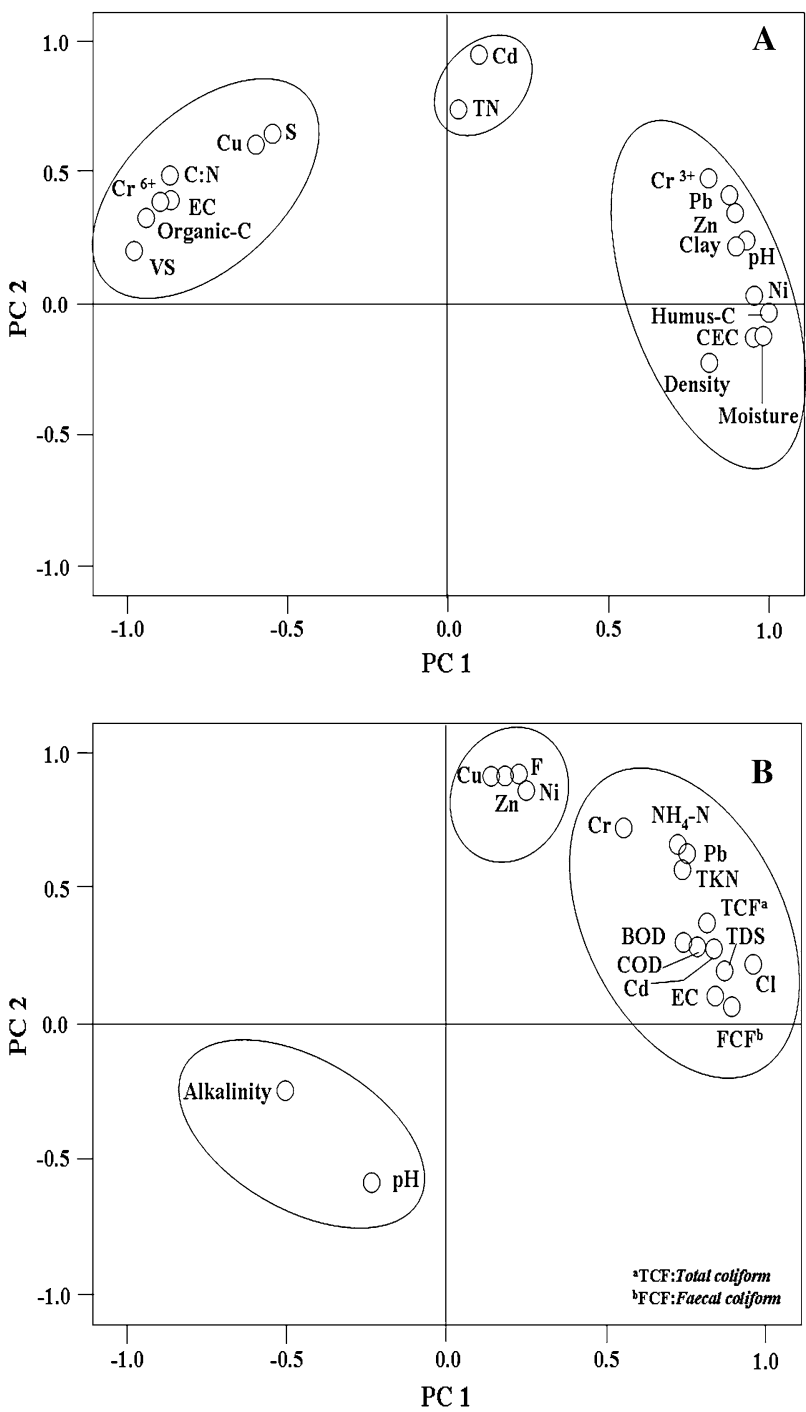

Fig. 5 a Orthogonal distribution of the principal component analysis (PCA) for all physical and chemical parameters in MSW $(\mathrm{PC} 1 \times \mathrm{PC} 2$ explains $75 \%$ of the total variance), b Orthogonal distribution of the principal component analysis (PCA) for the physical, chemical and biological parameters in liquid samples $(\mathrm{PC} 1 \times \mathrm{PC} 2$ explains $75 \%$ of the total variance)

among a set of variables (Iyer et al. 2003). Principal components are the linear combinations of original variables, and are the eigenvectors. The varimax rotation distributes the PC loadings such that their dispersion is maximized by minimizing the number of large and small coefficients (Richman 1986). The cornbach's alpha and Kaiser-Meyer-Olkin (KMO) sample adequacy showed the appropriate application of principal component and factor analysis in the present dataset. Two principal components extracted (eigenvalues greater than one) expressed about $90 \%$ of the total variability present in the system. The varimax rotated factors were extracted through PCA method. The results achieved by PCA through varimax rotation are shown in Fig. 5a, b. The biplot observed between PC1 and PC2 showed BOD, $\mathrm{Cd}, \mathrm{Cl}, \mathrm{COD}, \mathrm{Cr}, \mathrm{EC}$, $\mathrm{NH}_{4}-\mathrm{N}, \mathrm{Pb}, \mathrm{TCF}, \mathrm{TDS}, \mathrm{TN}, \mathrm{Cu}, \mathrm{F}, \mathrm{Ni}$ and $\mathrm{Zn}$ to be present in the second quadrant, suggesting strong association between these variables (Fig. 5b). It is observed that all the variables in MSW are separated into three different groups according to their characteristics. PC1 separates the variables into two different groups. One of them includes CEC, clay, $\mathrm{Cr}^{3+}$, density, humus-C, moisture, $\mathrm{Ni}, \mathrm{Pb}, \mathrm{pH}$ and $\mathrm{Zn}$, and the other group includes $\mathrm{Cd}$ and $\mathrm{TN}$, probably due to strong correlations among them (Thomsen et al. 2002). With PC2, it is possible to separate materials which have lower $\mathrm{C}$ : $\mathrm{N}, \mathrm{Cr}^{6+}, \mathrm{Cu}, \mathrm{EC}$ and higher TOC, $\mathrm{S}$ and $\mathrm{VS}$ (Fig. 5a).

PCA of the liquid data sets evolved three distinct groups (Fig. 5b). The PCs for first (BOD, Cd, Cl, COD, Cr, EC, $\mathrm{FCF}, \mathrm{NH}_{4}-\mathrm{N}, \mathrm{Pb}, \mathrm{TCF}$, TDS and $\left.\mathrm{TN}\right)$, second $(\mathrm{Cu}, \mathrm{F}, \mathrm{Ni}$ and $\mathrm{Zn}$ ) and third (alkalinity and $\mathrm{pH}$ ) groups with eigenvalues $>1$, explain $64.06,78.29$ and $87.02 \%$ of the total variance in liquid samples. PC1 explaining $75 \%$ of total variance has strong negative loadings $(>0.70)$ on $\mathrm{Cd}, \mathrm{Cr}$, $\mathrm{Pb}, \mathrm{Ni}$ and $\mathrm{Cu}$ and moderate negative loading on $\mathrm{Zn}$. Thus, it represents the metal group. PC1 also explaining $14.2 \%$ of the total variance has strong positive loadings on BOD and COD, and moderate loading on TN, which basically represents the organic pollutant group (Helena et al. 2000). TCF and FCF contribute $9.63 \%$, which points to a common origin for these bacteria. Both PC1 and PC2 have strong loading on HMs and coliform bacteria. Therefore, this indicates the influence of MSW dumping ground as the major source of water pollution particularly in relation to HMs in Deepor Beel mainly due to the mixing of leachate from MSW disposal sites. These findings are also in agreement with the physico-chemical-biological parameters in liquid samples (Table 2).

\section{Conclusion}

Present investigation revealed that HMs in the MSW changed significantly with sampling depths. Even though MSW samples collected from 2 to $3 \mathrm{~m}$ depth (MSW3) had the proposed visible physical standard of matured compost, it exceeded the prescribed limits for some HMs $(\mathrm{Cr}, \mathrm{Zn}$ and $\mathrm{Ni}$ ) and, therefore, it was unsuitable for agronomic application. However, the question of ecotoxicity, the environmental health and safety issues surrounding the application of this MSW compost in agricultural land remains to be fully resolved to meet the international standards, set for food and food chain. Besides this, the paper did not report any data on germination and/or plant growth test of MSW3 and, therefore, at this point MSW3 cannot be considered as a compost in 'as-is' conditions. The obtained data suggests that the prolonged application of this compost in 
agricultural land may increase the concentrations of HMs in the soil with time and thus may pose some future problems to human and animal health.

The sequential extraction of HMs in MSW showed that higher concentrations of $\mathrm{Zn}$ were associated with the soluble, exchangeable and carbonate fractions, whereas other HMs were mostly associated with the residual mineral components. The leachate quality analysis revealed the heterogeneity of solid waste and the methanogenic condition in the dumpsite. The possible dissolution of carbonate bound metals might be the result of acidic $\mathrm{pH}$ of the leachates. Since the presence of optimum moisture content in the waste influenced the degradation rate generating organic acid, it enhanced the concentration of heavy metal in the leachate runoff. The presence of TCF and FCF in surface water is a warning for the surface water quality for domestic purpose and other uses. The high contamination of Deepor Beel suggests that the run-off leachate from MSW was the major contributor of pollution. Although the uptake of HMs by different vegetables growing on MSW dumping site was within the safe limits, nevertheless, its consumption is questionable as it might act as a significant additional source of the HMs from the diet. PCA indicates that the major factors responsible for variation of water quality in Deepor Beel are mainly related to HMs, soluble salts, organic pollution and bacterial contamination, the main source of which is the MSW dumping site. Finally, the present investigation emphasized that there is an urgent need to adopt some management measures for protection of environmental quality in and around MSW landfill site.

Acknowledgments The authors are grateful to the anonymous reviewers for their insightful comments that have enabled them in improving the quality of the article. The authors gratefully acknowledge Dr. M. Hazarika, Director, Tocklai Experimental Station, Tea Research Association, Jorhat, Assam; Dr. Suhas Ghosh, Former Faculty Member, Chemistry Department, St. Paul's Cathedral Mission College, Kolkata, West Bengal, India and Dr. Sampa Das, Dibrugarh Polythechnic, Assam, India, for their valuable comments and helpful suggestions during the preparation of this manuscript. The authors are also thankful to Mr. Shyamal Chakravorty and Dr. Sukumar Debnath of Tocklai Experimental Station, Jorhat, Assam, India, for their valuable suggestions to improve the manuscript.

\section{References}

Adriano DC (1986) Trace elements in the terrestrial environment. Springer, New York

Alonso E, Callejon M, Jimenez JC, Ternero M (2002) Heavy metal extractable forms in sludge from wastewater treatment plants. Chemosphere 47(7):765-775

APHA (American Public Health Association) (1995) Standard methods for the examination of water and wastewater. Washington

Bhattacharyya P, Chakraborty A, Bhattacharya B, Chakrabarti K (2003) Evaluation of municipal solid waste compost as a component of integrated nutrient management in rain fed wetland rice. Compost Sci Util 11:343-350

Bhattacharyya P, Chakraborty A, Chakrabarti K, Tripathy S, Powell MA (2005) Chromium uptake by rice and accumulation in soil amended with municipal solid waste compost. Chemosphere 60(10):1481-1486

Bhattacharyya P, Mitra A, Chakrabarti K, Chattopadhyay DJ, Chakraborty A, Kim K (2008a) Effect of heavy metals on microbial biomass and activities in century old landfill soil. Environ Monit Assess 136(1-3) pp 299-306

Bhattacharyya P, Chakraborty A, Chakrabarti K, Tripathy S, Powell MA (2008b) Fractionation and bioavailability of lead in municipal solid waste compost and uptake by rice straw and grain under submerged condition. Geosci J 12(1):41-45

Biswas AK, Kumar S, Babu SS, Bhattacharyya JK, Chakrabarti T (2010) Studies on environmental quality in and around municipal solid waste dumpsite. Resour Conserv Recycl 55(2): 129-134

Bremner JM, Mulvaney RG (1982) Nitrogen total. In: Page AL, Miller RH, Keeney DR (eds) Methods of soil analysis. American Society of Agronomy, Madison, pp 575-624

Bureau of Indian Standard (BIS) 1999 Indian standard specification for drinking water. IS, 10500, New Delhi, India

Chian ESK, DeWalle FB (1976) Sanitary landfill leachates and their treatment. J Environ Eng 4(2):411-431

Doedens H, Cord-Landwehr K (1989) Leachate recirculation. In: Christensen TH, Cossu R, Stegmann R (eds) Sanitary landfilling: process, technology and environmental impact. Academic Press Ltd, London

Ehrig HJ (1983) Quality and quantity of sanitary landfill leachate. Waste Manage Res 83(1):53-68

Ehrig HJ, Scheelhaase T (1993) Pollution potential and long term behavior of sanitary landfills. In: Proceedings of the fourth international landfill symposium. Cagliari, Italy

Epstein E (1997) The science of composting. Technomic Publishing Co. Inc, Lancaster

Flyhammar P, Tamaddon F, Bengtsson L (1998) Heavy metals in a municipal solid waste deposition cell. Waste Manage Res 16(5):403-410

Fuentes A, Llorens M, Saez J, Aguilar MI, Ortuno JF, Meseguer VF (2004) Phytotoxicity and heavy metals speciation of stabilised sewage sludges. J Hazard Mater 108(3):161-169

He P, Shao L, Qu X, Li G, Lee D (2005) Effects of feed solutions on refuse hydrolysis and landfill leachate characteristics. Chemosphere 59(6):837-844

He P, Xiao Z, Shao LM, Yu JY, Lee DJ (2006) In situ distribution and characteristics of heavy metals in full-scale landfill layers. J Hazard Mater 137(3):1385-1394

Helena B, Pardo R, Vega M, Barrado E, Fernandez JM, Fernandez L (2000) Temporal evolution of groundwater composition in an alluvial aquifer (Pisuerga River, Spain) by principal component analysis. Water Res 34(3):807-816

Hogland W, Marques M (2003) Physical, biological and chemical processes during storage and spontaneous combustion of waste fuel. Resour Conserv Recycl 40(1):53-69

ICMR (Indian Council of Medical Research) (2001) Health Guide. New Delhi, India

Iyer CS, Sindhu M, Kulkarni SG, Tambe SS, Kulkarni BD (2003) Statistical analysis of the physico chemical data on the coastal waters of Cochin. J Environ Monit 5(2):324-327

Jackson ML (1995) Soil chemical analysis. Prentice Hall of India, New Delhi

Karak T, Bhagat RM, Bhattacharyya P (2012) Municipal solid waste generation, composition and management: The world scenario. Critical Rev Environ Sci Technol 42(15):1509-1630 
Keon NE, Swartz CH, Brabander DJ, Harvey C, Hemond HF (2001) Validation of an arsenic sequential extraction method for evaluating mobility in sediments. Environ Sci Technol 35(13): 2778-2784

Kjeldsen P, Barlaz MA, Rooker AP, Baun A, Ledin A, Christensen TH (2002) Present and long term composition of MSW landfill leachate: a review. Crit Rev Environ Sci Technol 32(4):297-336

Kumar S, Gaikwad SA (2004) Municipal solid waste management in Indian urban centres: an approach for betterment, urban development debates in the new millennium. Atlantic Publishers \& Distributors, New Delhi

Lax A, Roig A, Costa F (1986) A method for determining the cationexchange capacity of organic materials. Plant Soil 94(3): 349-355

Lo I (1996) Characteristics and treatment of leachates from domestic landfills. Environ Int 22(4):433-442

Mitra A, Bhattacharyya P, Chattopadhyay DJ, Chakraborty A, Chakrabarti K (2003) Physico-chemical properties, heavy metals and their relations in cultivated landfill soils dumped with municipal solid wastes. Arch Agron Soil Sci 49(2):163-170

Municipal Solid Wastes (Management and Handling) Rules (2000) Ministry of environment and forests. Govt of India, New Delhi

Narwal RP, Singh BR (1998) Effect of organic materials on partitioning, extractability and plant uptake of metals in an alum shale soil. Water Air Soil Pollut 103(1-4):405-421

Neill M (2004) Microbiological Indices for total coliform and E. coli bacteria in estuarine waters. Mar Pollut Bull 49(9-10):752-760

Nelson DW, Sommers LE (1982) Total carbon, organic carbon, and organic matter. In: Page AL, Miller RH, Keeney DR (ed) Methods of soil analysis. Part 2 Chemical and microbiological properties, 2nd edn, American Society of Agronomy and Soil Science Society of America, Wisconsin pp 539-79

Ostman M, Wahlberg O, Agren S, Matensson AM (2006) Metal and organic matter contents in a combined household and industrial landfill. Waste Manage (Oxford) 26(1):29-40

Oygard JK, Gjengedal E, Royset O (2007) Size charge fractionation of metals in municipal solid waste landfill leachate. Water Res 41(1):47-54

Ozturk I, Altinbas M, Koyuncu I, Arikan O, Gomec-Yangin C (2003) Advanced physico-chemical treatment experiences on young municipal landfill leachates. Waste Manage (Oxford) 23(5): $441-446$

Prechthai T, Parkpian P, Visvanathan C (2008) Assessment of heavy metal contamination and its mobilization from municipal solid waste open dumping site. J Hazard Mater 156(1-3):86-94

Reinhart DR, Al-Yousfi AB (1996) The impact of leachate recirculation on municipal solid waste landfill operating characteristic. Waste Manage Res 14(4):337-346

Renou S, Givaudan JG, Poulain S, Dirassouyan F, Moulin P (2008) Landfill leachate treatment: review and opportunity. J Hazard Mater 150(3):468-493

Richman MB (1986) Rotation of principal components. Int J Climatol 6(3):293-335

Robinson AH (2005) Landfill leachate treatment. Membr Technol $6: 6-12$
Rudel H, Terytze K (1999) Determination of extractable chromium (VI) in soils using a photometric method. Chemosphere 39(4): 697-708

Sanchez-Monedero MA, Roig A, Martinez-Pardo C, Cegarra J, Paredes C (1996) A microanalysis method for determining total organic carbon in extracts of humic substances. Relationships between total organic carbon and oxidable carbon. Bioresour Technol 57(3):291-295

Sharholy M, Ahmad K, Mahmood G, Trivedi RC (2008) Municipal solid waste management in Indian cities-A review. Waste Manage (Oxford) 28(2):459-467

Shekdar AV (2009) Sustainable solid waste management: integrated approach for Asian countries. J Waste Manage 29(4):1438-1448

Tchobanoglous G, Theisen H, Vigil SA (1993) Integrated solid waste management. McGraw-Hill Inc, USA

Tessier A, Campbell PGC, Bisson M (1979) Sequential extraction procedure for the speciation of particulate trace metals. Anal Chem 51(7):844-850

Thauer RK (1998) Biochemistry of methanogenesis: a tribute to Marjory Stephenson. Microbiology 144(9):2377-2406

Thomsen M, Lassen P, Dobel SP, Hansen E, Carlsen L, Mogensen BB (2002) Characterisation of humic materials of different origin: a multivariate approach for quantifying the latent properties of dissolved organic matter. Chemosphere 49(10):1327-1337

Tripathi RM, Raghunath R, Krishnamoorthy TM (1997) Dietary intake of heavy metals in Bombay city, India. Sci Total Environ 208(3):149-159

UNICEF (1999) WATER front, fluoride in water: an overview. UNICEF Programme Division, WES Section, USA

US Environmental Protection Agency (2007) SW-846 test methods for evaluating solid wastes, December 26. http://www.epa.gov/ sw-846/main.htm

USEPA (United States Environmental Protection Agency) (1999) Standard for the use or disposal of sewage sludge, 40 CFR Part 503 sewage sludge rule. Federal Registe, USA

Weast R, Astle MJ, Beyer WH (1985) CRC handbook of chemistry and physics. CRC Press Inc, Boca Ranton

WHO (World Health Organization) (1993) Evaluation of certain food additives and contaminants, WHO technical report series, number 837. World Health Organization, Geneva

WHO (World Health Organization) (1997) Guideline for drinking water quality health criteria and other supporting information, 2nd edn, Geneva

Xiaoli C, Shimaoka T, Xianyan C, Qiang G, Youcai Z (2007) Characteristics and mobility of heavy metals in an MSW landfill: implication in risk assessment and reclamation. J Hazard Mater 144(1-2):485-491

Ysart GE, Miller PF, Crews H, Robb P, Baxter M, Delargy C, Lofthouse S, Sargent C, Harrison N (1999) Dietary exposure estimates of 30 metals and other elements from the UK total diet study. Food Addit Contam 16(9):391-403

Zucconi F, Pera A, Forte M, de Bertoldi M (1981) Evaluating toxicity of immature compost. Biocycle 22:54-57 